\title{
Induction and characterization of oil palm (Elaeis guineensis Jacq.) pro-embryogenic masses
}

\author{
MARLÚCIA S. PÁDUA ${ }^{1}$, LUCIANO V. PAIVA ${ }^{1}$, CLAÚDIA R.G. LABORY ${ }^{2}$, \\ EDUARDO ALVES ${ }^{2}$ and VANESSA C. STEIN ${ }^{3}$ \\ ${ }^{1}$ Laboratório Central de Biologia Molecular, Universidade Federal de Lavras/UFLA, 37200-000 Lavras, MG, Brasil \\ ${ }^{2}$ Departamento de Fitopatologia, Laboratório de Microscopia Eletrônica e Ultra-estrutural, \\ Universidade Federal de Lavras/UFLA, 37200-000 Lavras, MG, Brasil \\ ${ }^{3}$ Laboratório de Fisiologia Vegetal, Universidade Federal de Goiás, \\ Campus Jataí, BR 364, Km 192, n 3800, Sala 416, Setor Industrial, 75801-615 Jataí, GO, Brasil
}

Manuscript received on July 4, 2012; accepted for publication on April 8, 2013

\begin{abstract}
Oil palm is one of the most economically valuable oil seed plants, but the expansion of plantations has been limited by availability of seedlings, as the conventional propagation is through seeds, which have low germination rates. One possible solution for the large-scale production is the use of somatic embryogenesis. The aim of this study was evaluate the effects auxins 2,4-D and picloram on the induction of pro-embryogenic masses in E.guineenesis hybrid leaf explants and characterize, regarding embryogenic characteristics, with cytochemical and ultrastructural analisys. Specifically, in vitro plantlets leaves fragments were inoculated in Y3 culture medium supplemented by 2.4-D or picloram at different concentrations $(0.0,1.0,3.0,6.0$ and 9.0 $\left.\mathrm{mg} \mathrm{l}^{-1}\right)$. After 90 days the presence/ absence of cell masses were evaluated. Both growth regulators efficiently induced cellular masses regardless of the concentrations applied. As the cell masses were not homogeneously formed, they were classified according to color and shape into four types: TYPE 1 - elongated and translucent, TYPE 2 - uneven and translucent, TYPE 3 - globular and beige TYPE 4 - globular and white. Based on the anatomical and ultrastructural features, TYPE 2, 3 and 4 cell masses were considered to have the highest embryogenic potential and therefore may be most suited to large-scale vegetative propagation of oil palm.
\end{abstract}

Key words: embryogenic potential, growth regulators, tissue culture, transmission electron microscopy.

\section{INTRODUCTION}

The oil palm (Elaeis guineensis Jacq. var Tenera) is one of the most economically valuable oil seed plants due to its high oil yield per bunch - reaching up to $6,000 \mathrm{~kg}$ ha- 1 for certain genotypes. Palm oil is of high quality and is widely used in the food, medicine and cosmetic industries. Morover, as with other vegetable oils, palm oil can be used to create biodiesel through mixing with petrodiesel

Correspondence to: Marlúcia Souza Pádua

E-mail:marluciabio@yahoo.com.br or through transesterification (Benjumea et al. 2008, Ghassan et al. 2003).

In order to expand oil palm cultivation and increase biofuel supply, the Brazilian government has recently launched the National Biofuels Programme (Agroanalysis 2007). However, expansion of oil palm plantations has been limited by availability of seedlings, as the conventional propagation is through seeds, which have low germination rates and require a substantial period (1-3 years) to produce seedlings (Martine et al. 2009, Luis et al. 2010). 
In vitro propagation is an efficient alternative for the large-scale propagation of many species (Kanchanapoom and Domyoas 1999, Steinmacher et al. 2007), including the oil palm (Duval et al. 1988). Somatic embryogenesis is an in vitro propagation method that allows, the production of plants from diploid cells without gamete fusion and is one of the most promising methods for cultivation of palm oil (Thomas and Rao 1985). This method ensures the maintenance of important agronomic characteristics and the healthy quality of seedlings. Somatic embryogenesis can occur in vitro in two ways: (i) indirectly, with an intermediate phase characterized by callus formation, and; (ii) directly, without previous callus formation (Guerra et al. 1998). During the indirect somatic embryogenesis different types of callus are frequently produced, some of which have potential to generate plants. Identification of callus cells with embryogenic potential can be achieved through cytological and ultrastructural analysis (Fillipi et al. 2001, Steiner et al. 2005, Moura et al. 2008), thereby greatly enhancing the efficiency of the in vitro propagation process.

The aim of this work was to evaluate the effect of the growth regulators 2,4-D and picloran on the induction of pro-embriogenic masses from oil palm (Elaeis guineensis Jacq. var Tenera) leaf explants. Embriogenic potential of explants was evaluated through cytochemical and ultrastructural analysis.

\section{MATERIALS AND METHODS}

\section{PLANT MATERIAL}

This research was performed at the Central Laboratory of Molecular Biology and at Laboratory of Electron Microscopy and Ultraestrututral Analysis (LME), both belonging to the Federal University of Lavras, Minas Gerais State, Brazil. Immature fruits of E. guineensis hybrid Tenera were provided by the company Denpasa, located in Para State, northern Brazil. The fruits (collected approximately 90 to 100 days after pollination) were washed in sodium hypochlorite (1.25\%) and broken to remove the epicarp, mesocarp and endocarp therby exposing the kernels. These were washed in water and placed in a laminar flow chamber for disinfection. The kernels were immersed in $70 \%$ ethanol for 30 seconds, then placed in sodium hypochlorite $(1.25 \%)$ containing Tween, and finally they were washed three times in sterile distilled water under continuous stirring. After disinfection, the embryos were isolated from the kernels and inoculated in a Petri dish containing a modified Y3 culture medium (Eeuwens 1978) supplemented with $45 \mathrm{~g} \mathrm{~L}^{-1}$ of sucrose, $0.6 \%$ (w/v) of agar and $\mathrm{pH}$ adjusted to $5.7 \pm 0.1$. The inoculated embryos were maintained on a photoperiod of 16 hours at 26 $\pm 2{ }^{\circ} \mathrm{C}$. Every 30 days the embryo were subcultured to flasks containing fresh culture medium.

SOMATIC EMBRYOGENESIS INDUCTION

Leaves of in vitro plants were used for incuction of pro-embryogenic masses. The leaves explants (aproximatelly $0.5 \mathrm{~cm}$ ) were inoculated with the adaxial side in contact with the Y3 culture medium (Eeuwens 1978) supplemented with picloram (4-amin acid-3,5,6 - triclor-2-pyridinecarboxylic acid) or 2,4-D (2,4-dichlorophenoxyacetic) at concentrations of 0,1 , 3,6 e 9 mg. $\mathrm{L}^{-1}$. Culture media were suplemented with sucrose $(3 \%)$, solidified with agar $(0.6 \%)$ and the $\mathrm{pH}$ were adjusted to $5.7 \pm 0.1$. After inoculation, the explants were mantained in a growth chamber in the dark at a temperature of $27 \pm 2^{\circ} \mathrm{C}$. After 90 days the percentage, morphology and color of masses were evaluated.

The presence and absence of cell masses in the leaf explants were assessed through analysis of variance and the averages were compared by Generalized Linear Models. All statistical analysis was performed using $\operatorname{SAS}^{\circledR}$ v. 9.3.

\section{HisTOCHEMICAL AND MORPHOLOGIC ANALYSIS} of CELl MASSES

The cell masses were fixed in FAA (formaldehyde, acetic acid and alcohol) for 72 hours and transferred 
to $70 \%$ ethanol. After fixing, masses were placed in a $50 \%$ alcohol + resin solution overnight and were then transferred to pure resin for $48 \mathrm{~h}$. Finally, they were embedded in Leica resin according to the manufacturer's protocol. Embedded samples were sectioned with a thickness of $5 \mathrm{~mm}$ using a rotary microtome and stained with toluidine blue $0.05 \%$ solution or lugol solution. The stained sections were then mounted on slides and observed with a photonic Zeizz Scope.A1 microscope with attached camera.

Transmission EleCtron Microscopy OF THE CELL MASSES

For analysis in the transmission electron microscope (Zeiss EM 109), samples of cell masses were immersed in fixative (modified Karnovsky, $2.5 \%$ glutaraldehyde, $2.0 \%$ paraformaldehyde, $0.05 \mathrm{M}$ cacodylate buffer, $\mathrm{pH}$ 7.2) for 24 hours and prepared according to the protocol described by Bossola and Russel (1999).

\section{RESULTS AND DISCUSSION}

Both growth regulators (2,4-D and picloram, added to the culture medium Y3) efficiently induced cellular masses in leaves of the oil palm E. guineensis var. tenera. These masses cellular formed regardless of the growth regulator type and of the concentration used (Figure 1). Moreover, callus formation was not detected in the absence of growth regulators (Figure 2).

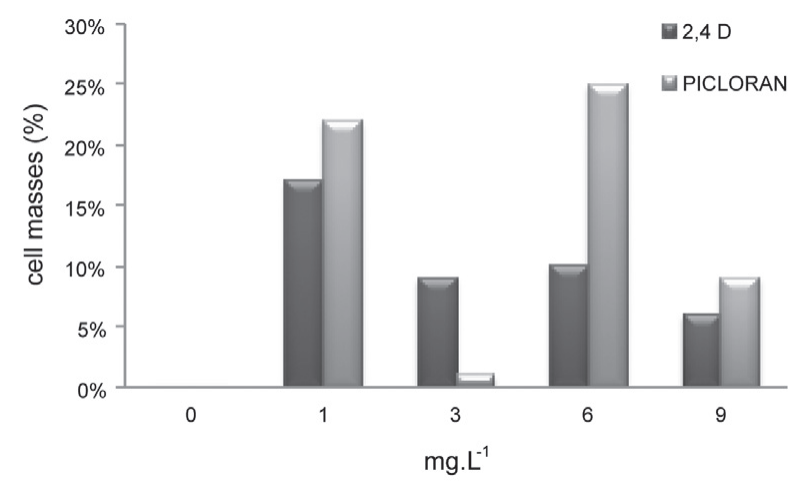

Figure 1 - Callus percentage on oil palm tenera hybrid (Elaeis guineensis) leaves induced with 2,4D and picloran.
The morphology and staining of the cell masses were not homogeneous, and it was possible to classify them into four types (Figure 2): TYPE 1, elongated and translucent; TYPE 2, uneven and translucent; TYPE 3 globular and beige, and; TYPE 4 globular and white.

These results are similar to those of Bravin et al. (2006), who describe the proliferation of four different callus types on leaf explants of Hypnea musciformis. The formation of different types of callus has also been observed in oats Avena sativa (Lamb et al. 2002). In this case the phenotypically distinct callus were classified as embryogenic (yellow and friable), organogenic (whitish) or unable to generate plants (watery and translucent).

A greater proportion of TYPE 1 cell masses were generated in the culture medium with the lowest dose of 2,4-D (1 mg L $\left.{ }^{-1}\right)$ (Figure 1a). In contrast, culture media containing the picloram had a low proportion of this type of cell masses (Figure 3a). Type 2 cell masses were only generated on the treatment contained growth regulator 2,4-D at a concentration of $3 \mathrm{mg} . \mathrm{L}^{-1}$ (Figure 3b), while TYPE 3 cell masses were observed more frequently on the 1,6 and $9 \mathrm{mg} \mathrm{L}^{-1}$ picloram treatments (Figure 3c). Type 4 cell masses were obtained on the $3 \mathrm{mg} . \mathrm{L}^{-1}$ treatment of $2.4-\mathrm{D}$ and on the $1 \mathrm{mg} . \mathrm{L}^{-1}$ and 9 mg. $L^{-1}$ picloram treatments (Figure $3 \mathrm{~d}$ ).

Callus external characteristics may be speciesspecific, hindering standardization of external morphology criteria to identify embryogenic potential. Such potential can, however, be potentially identified on the basis of cytological features. Histochemical analysis of TYPE 1 cell masses indicated the presence of dispersed elongated cells (Figure 4), without the deposition of starch grains (Figure 4b). TYPE 2 cell masses consisted of small isodiametric cells (Figure $4 c)$ with clear accumulation of starch grains which were very apparent with lugol (Figure 4d). TYPE 3 cell masses were also characterized by small isodiametric cells and accumulation of starch grains (Figure 4e). These masses also contained globular structures with differentiation sites representing meristematic centers 

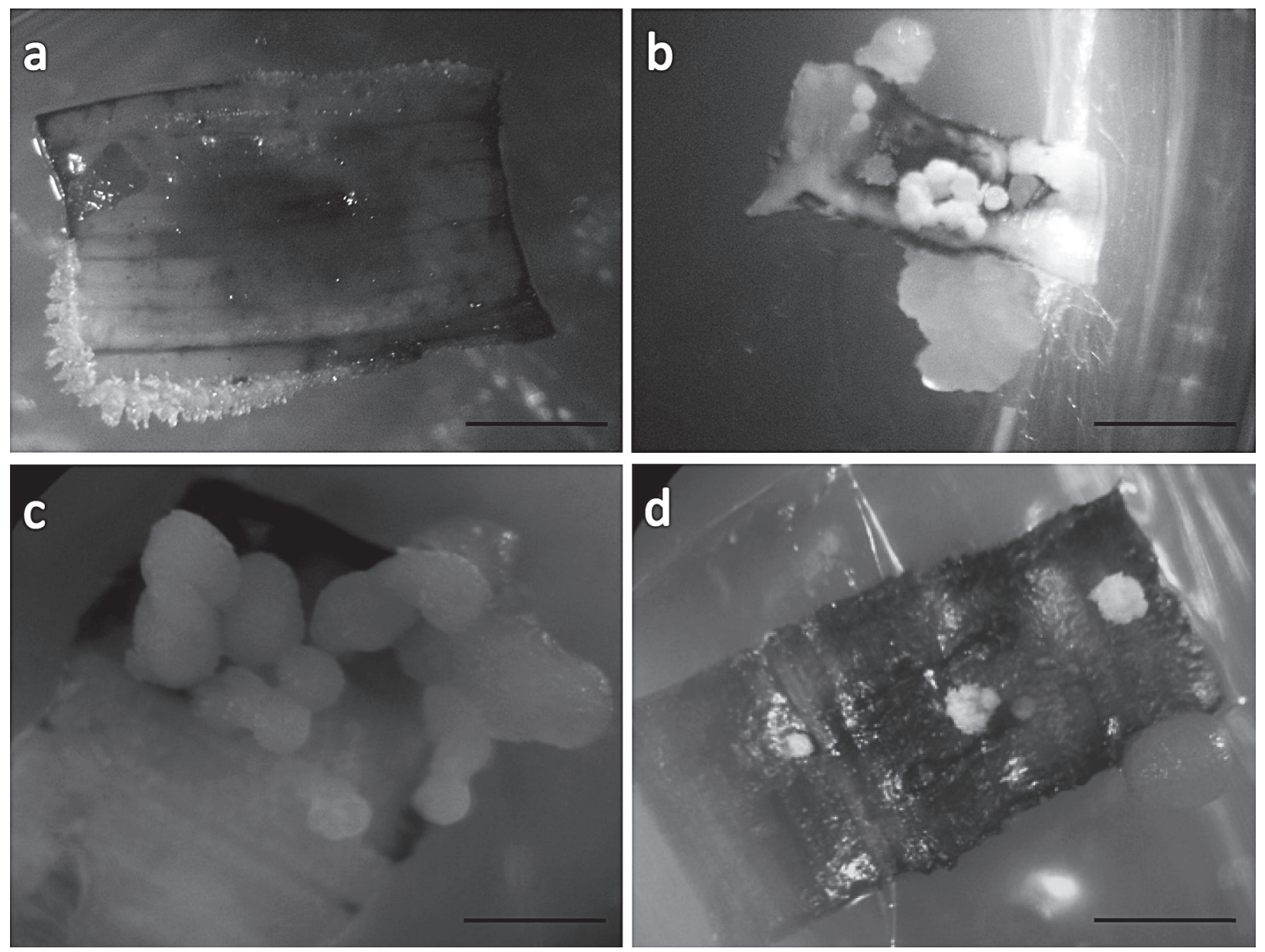

Figure 2 - Stereomicrographs of callus produced on oil palm tenera hybrid (Elaeis guineensis) leaves. A) Type 1 - elongated and translucent; B) Type 2 - uneven and translucent; C) Type 3 - globular and beige; D) Type 4 - globular and white. Bar $=0.25 \mathrm{~mm}$.

with initial formation of procambium. Some cells were observed shedding around these globular structures (Figure 4f). Type 4 cell masses also contained globular structures formed by small isodiametric cells, contain starch grains and cells shedding around the globular structures (Figure 4g) and other cells (Figure 4h).

Different cell mass formantions have been observed in the callus of Araucaria angustifolia (Steiner et al. 2005). In this case, some cell masses contained small isodiametric cells which formed embryogenic clusters from which subsequently originated proembryos. Other masses had elongate and vacuolated cells similar to the TYPE 1 masses observed in the present study. These masses did not produce embryos.
Cell masses belonging to TYPES 2, 3 and 4 were characterized by the deposition of starch grains (Figure 4d, 4f and 4h). Starch storage in the embryo, embryogenic cells or in adjacent cells usually indicates the acquisition of embryogenic competence (Moura 2008) as starch grains being produced to support and initiate the development of somatic embryos. Large amounts of starch have been observed in embryogenic callus cells of Gentiana punctata, as source of energy for intense cell division and for development of the embryo (Mikula et al. 2004). On the peach palm (Bactris gasipaes) the accumulation of starch has been observed to precede the development of somatic embryos (Steinmacher et al. 2011). 
a)

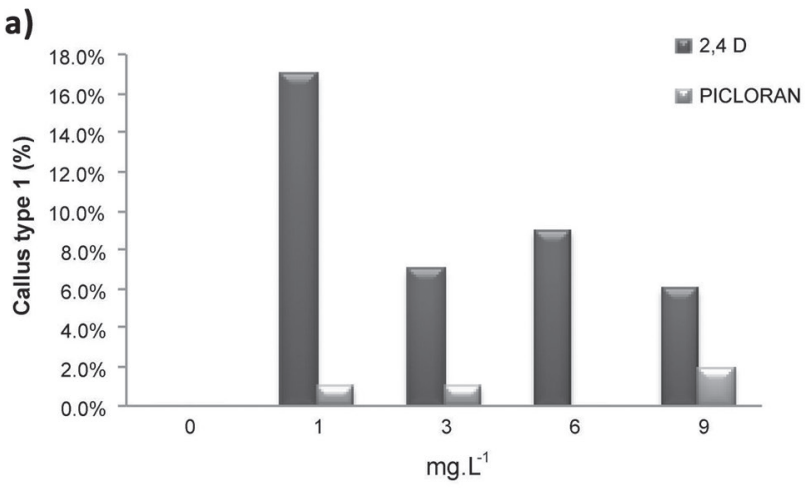

c)

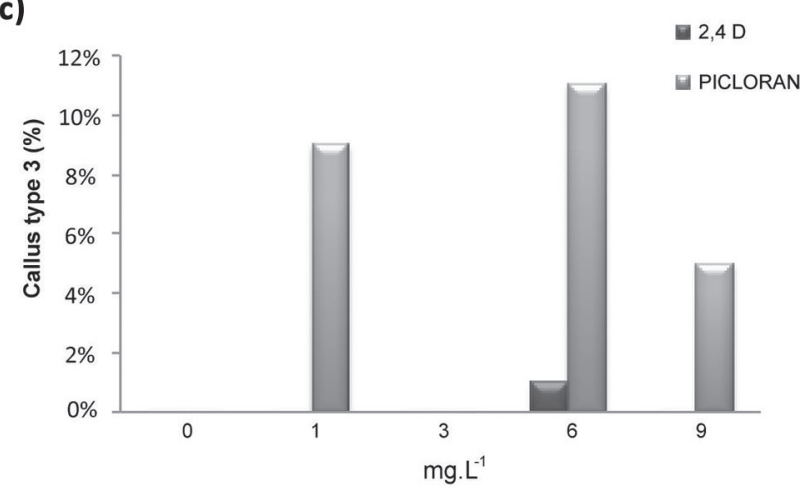

b)

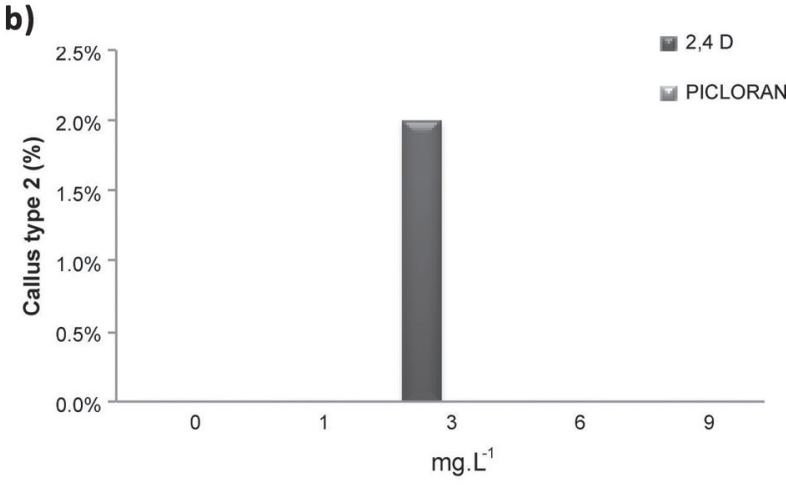

d)

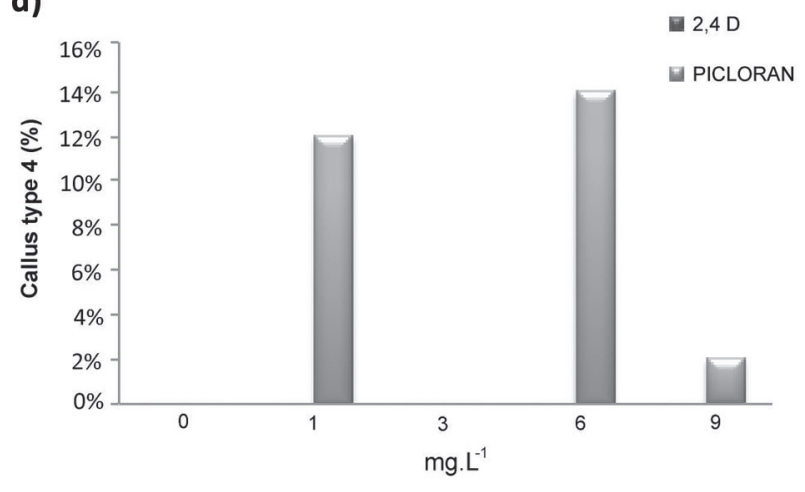

Figure 3 - Callus type percentage of oil palm tenera hybrid (Elaeis guineensis) induced on different 2,4D and picloran. A) Type 1, B) Type 2, C) Type 3, and D) Type 4.

Similar observations were made in embryogenic cells of Feijoa sellowiana, which are characterized by a well-developed nucleus with prominent nucleoli and starch grains (Canhoto et. al 1996). Once again, the starch grains are thought to provide energy for the development of the somatic embryos, suggesting active regulation of starch grain accumulation in embryogenic cells (Martin et al. 2000).

The ultrastructural analysis indicated that TYPE 1 cell masses had large vacuoles (Figure 5a), diffuse cytoplasm (Figure 5b) and intercellular spaces (Figure 5c) within elongated cells (Figure 1a). Such elongated cells are not embryogenic and the vacuolation is considered as an early marker of cell death (Filonova et al. 2000, Lam et al. 2000). Based on these characteristics, Type 1 cell masses probably have no embryogenic potential.

TYPE 2 cells were characterized by a nucleus with prominent nucleoli, dense cytoplasm, high nucleus/cytoplasm ratio, the presence of amiloplasts close to the nucleus (Figure 6), thick walls with little intercellular space, mitochondria and numerous plasmodesmata (Figure 6). TYPE 3 cells had a nucleus with nucleoli apparent, many amyloplasts, mitochondria, endoplasmic reticulum, phenols, lipids, and thin cell walls (Figure 8). It was also possible to observed thick cell walls with few intercellular spaces in TYPE 4 cells, which also contained many mitochondria and amyloplasts (Figure 9).

Callus cells of the coconut palm (Cocos nucifera) have a similar ultrastructure to TYPE 2 cell masses, being characterized by large nuclei with two nucleoli, cell walls with uniform thickness, amyloplasts and plasmodesmata (Verdeil et al. 2001). Plasmodesmata are channels that connect neighboring cells allowing the exchange of structural and functional molecules at a faster rate than transport through membranes (Concenço et al. 2007). 


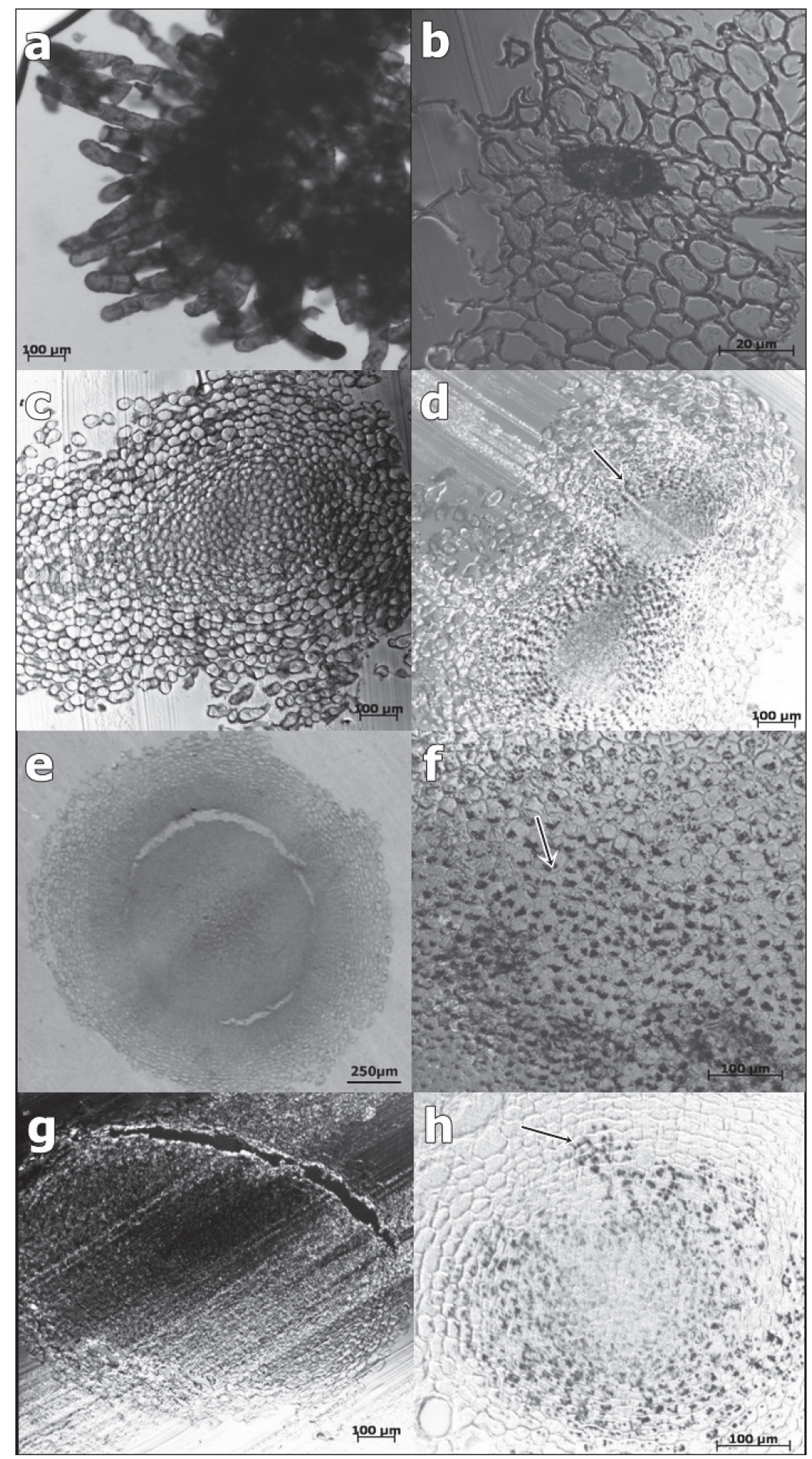

Figure 4 - Histochemical analysis of oil palm tenera hybrid (Elaeis guineensis) callus leaves induced with 2,4D and picloran A) Callus Type 1 stained with toluidine blue. Elongated and dispersed cells (arrows); B) Callus Type 1 stained with Lugol; C) Callus Type 2. Cells strongly stained with toluidine blue (arrows); D) Callus Type 2 stained with Lugol. Starch grains (arrows); E) Callus Type 3 stained with toluidine blue. Globular structure with procambium (Pc); F) Callus Type 3 with starch grains stained with lugol (arrows). G) Callus Type 4 stained with toluidine blue. Isodiametric small cell H) Callus Type 4. Starch grains stained with lugol. Procambium. 

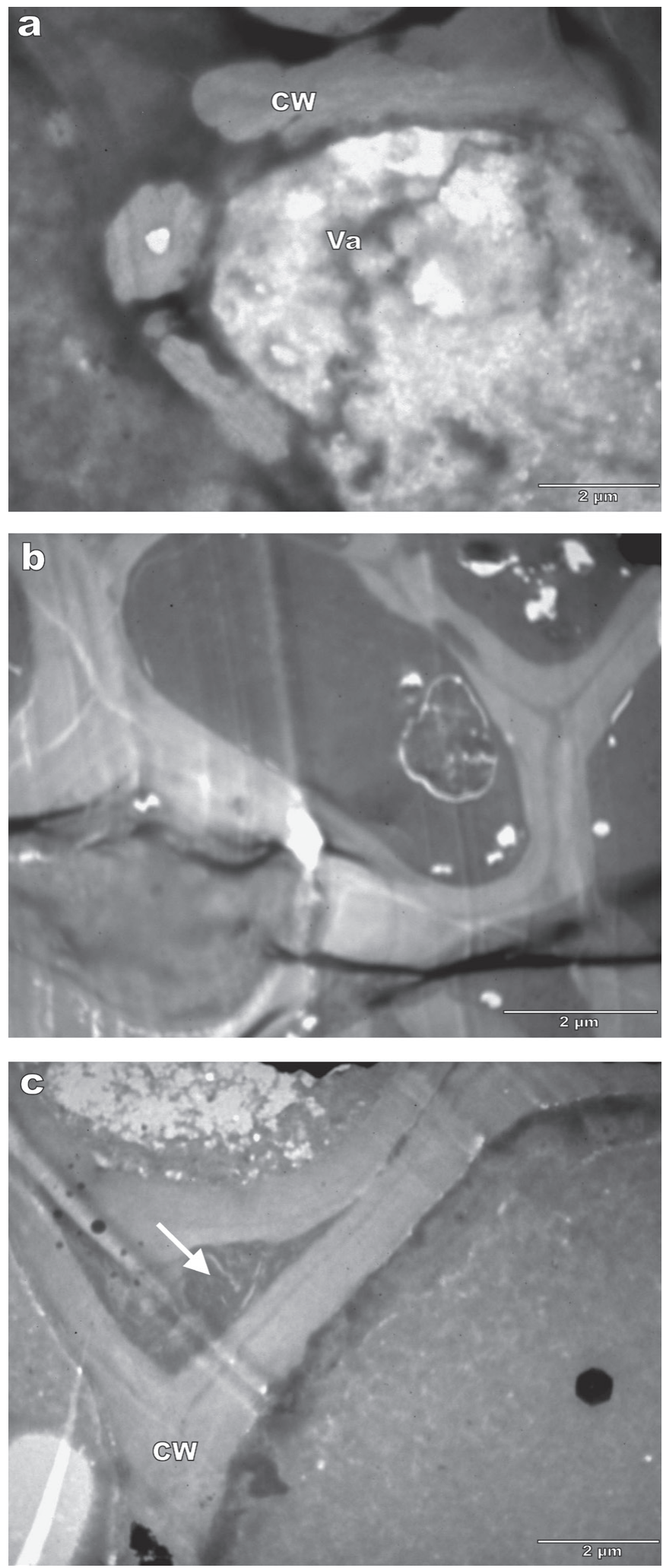

Figure 5 - Transmission electron micrographs of the callus Type 1 A) Large vacuole, narrow cytoplasm and cell wall rupture (arrows). B) Cells. C) Large intercellular spaces (arrows), cell wall (CW) and large vacuole (Va). 

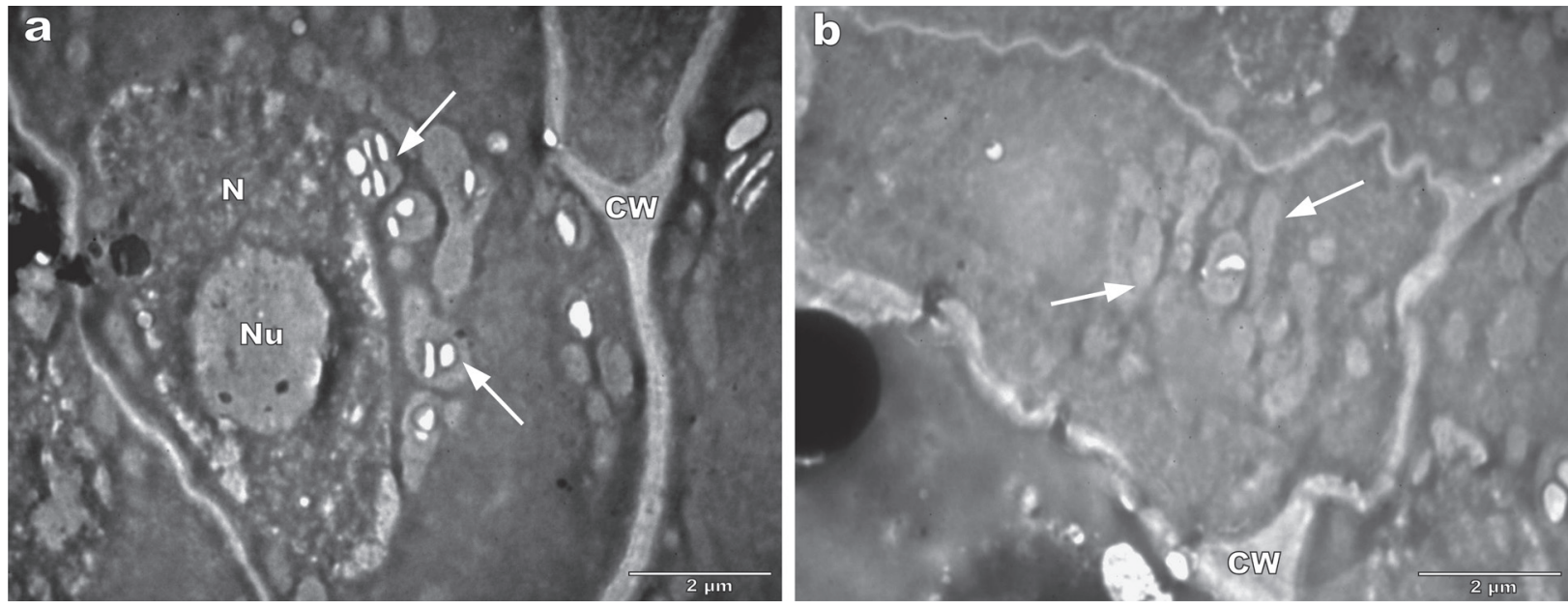

Figure 6 - Transmission electron micrographs of the callus Type 2. A) Large nuclei, prominent nucleoli and amyloplasts (arrow). B) Mitochondria (arrows), cell wall $(\mathrm{CW})$, nucleus $(\mathrm{N})$ and nucleolus $(\mathrm{Nu})$.
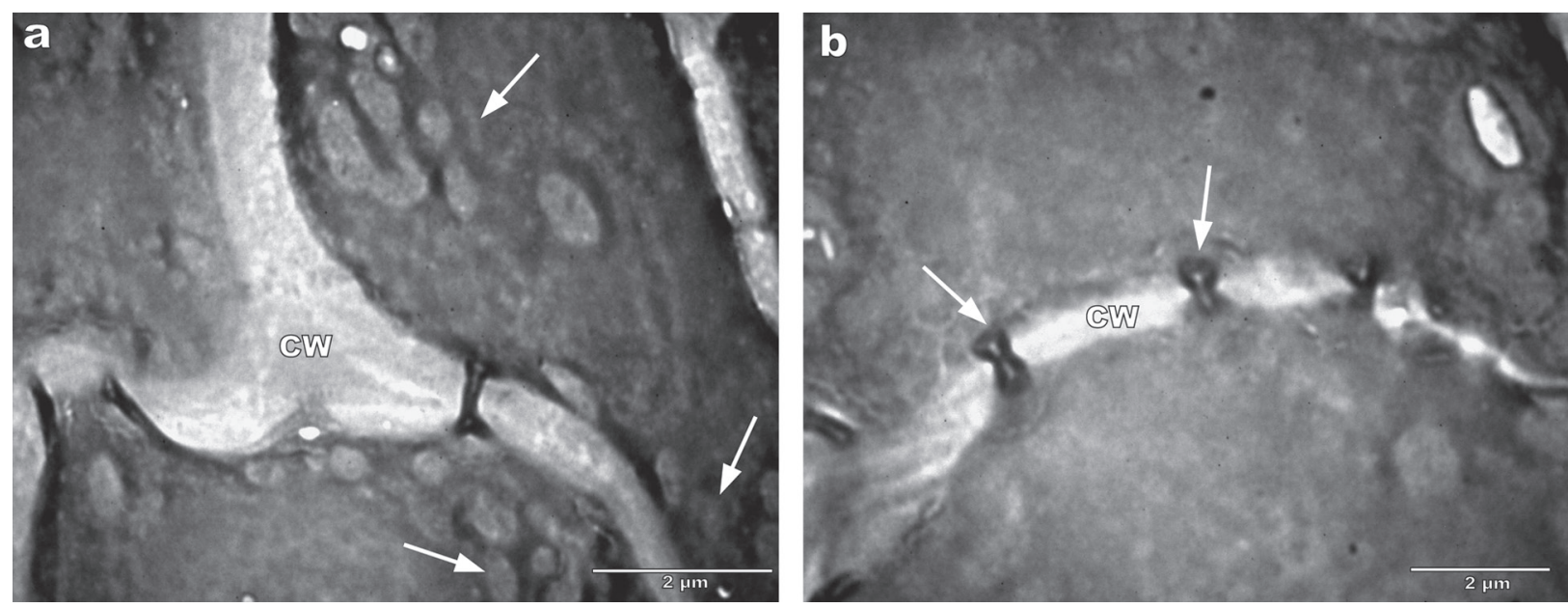

Figure 7 - Transmission electron micrographs of the callus Type 2. A) Thick cell wall with few gaps between the cell. Mitochondria (arrows). B) Plasmodesmata (arrows) and cell wall (CW).

Embryogenic cells undergo changes when acquire the competence to form pro-embryos as: cell wall thickening, surrounding tissues senescence, increase of amiloplasts around the nucleus, no spherical nucleus and consequentilly numerous mitotic divisions. After of the pro-embryos formation the cells return to meristematic cells features with spherical nucleus, less amiloplasts aroud of the nucleus, thin cell wall and formations of plasmodesmata (Verdeil et al. 2001).

Date-palm (Phoenix dactylifera) somatic embryos are characterized by small cells with meristematic characteristics, dense nuclei and cytoplasm (Aslam et al. 2011), and are therefore histologically similar to the globular structures observed in TYPE 3 cell masses. These embryogenic characteristics (large nuclei with prominent nucleoli, mitochondria, and starch grains) have also observed in the callus of Inga (Stein et al. 2010). In Feijoa sellowiana, cells with embryogenic characteristics had well-developed nuclei with prominent nucleoli, many mitochondria and starch granules (Canhoto et al. 1996). The presence of numerous mitochondria is related to high cell metabolism because this organelle is responsible for cellular respiration. 

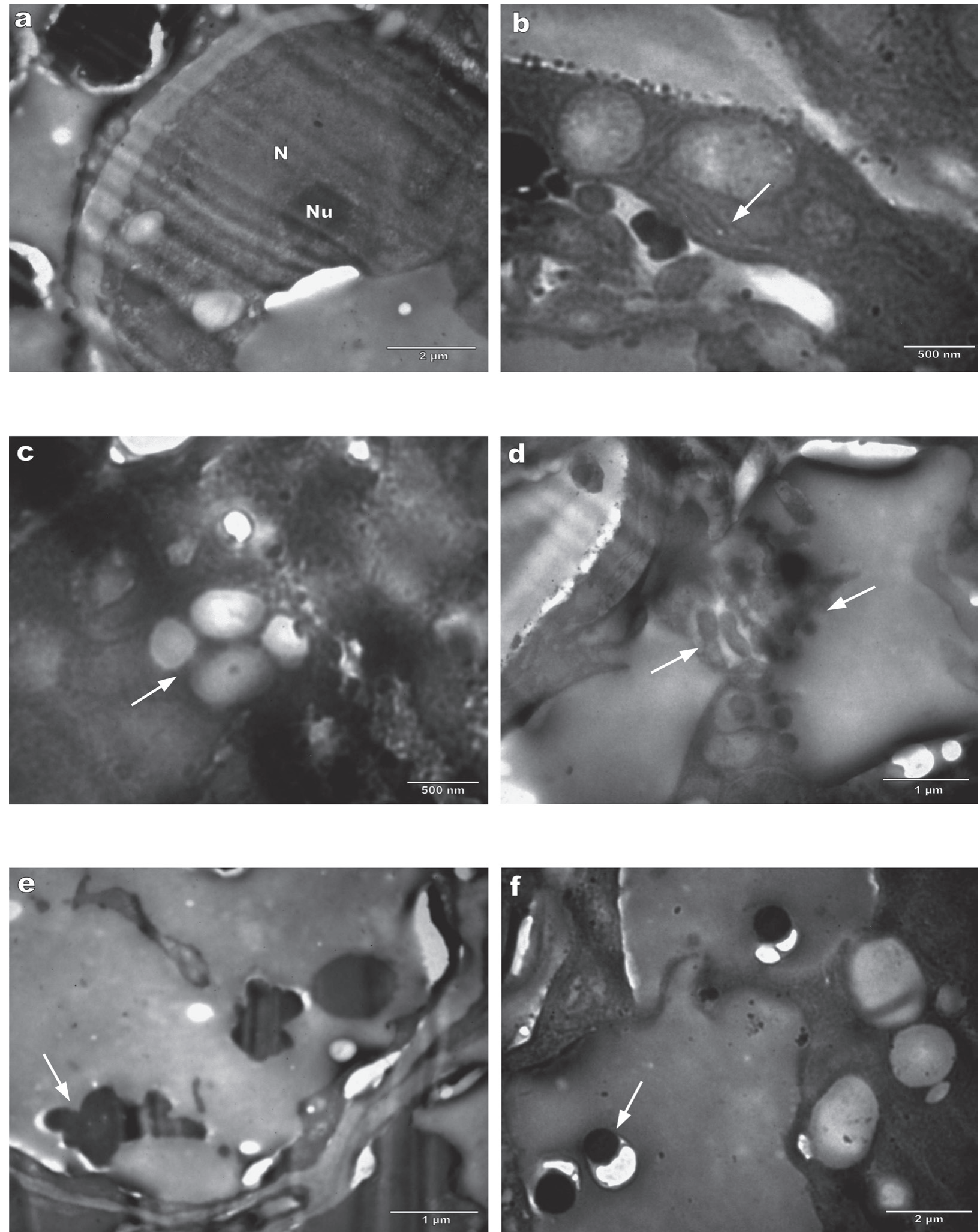

Figure 8 - Transmission electron micrographs of the callus Type 3. A) Large nucleus, nucleolus and thick cell wall. B) Endoplasmic reticulum (arrows). C) Numerous amyloplasts (arrows). D) Mitochondria (arrows) E) and F) Phenols (arrows). 

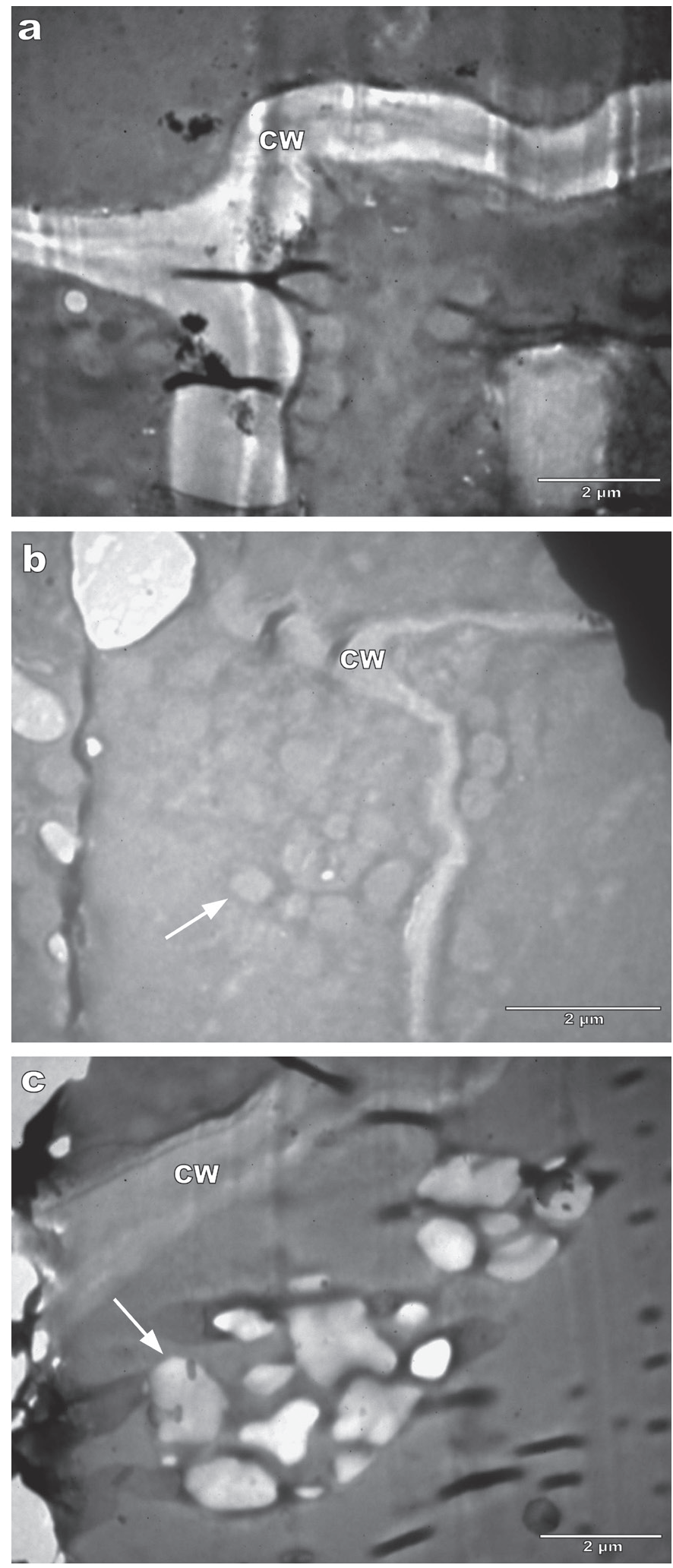

Figura 9 - Transmission electron micrographs of the callus Type 4. A) Thin cell wall. B) Numerous mitochondria (arrows) and C) amyloplasts (arrows). Cell Wall (CW). 


\section{CONCLUSIONS}

The culture medium supplemented with the auxins 2,4-D and picloram successfully promoted the formation of four types of cell masses, regardless of the concentrations of growth regulator.

TYPE 1 cell masses had no embryogenic characteristics, being composed of elongated vacuolated cells and with degraded cell walls indicating apoptosis.

The growth regulator picloram (at a concentration of $\left.1 \mathrm{mg} . \mathrm{L}^{-1}\right)$ is most effective at inducing Type 3 and 4 pro-embryogenic masses.

Based on ultrastructural characteristics and on production of pro-embryogenic masses, TYPE 3 cell masses are most suitable for regeneration of oil palm through somatic embryogenesis.

\section{ACKNOWLEDGMENTS}

We thank the Coordenação de Aperfeiçoamento Pessoal de Nível Superior (CAPES) for scholarship granted to the first author and the Conselho Nacional de Desenvolvimento Científico e Tecnológico (CNPq) and Fundação de Amparo à Pesquisa do Estado de Minas Gerais (FAPEMIG) for financial support to the Laboratorio Central de Biologia Molecular and Laboratório de Microscopia Eletrônica e Análise Ultraestrutural at the Universidade Federal de Lavras.

\section{RESUMO}

O dendezeiro é uma das oleoginosas mais importante economicamente, mas a expansão das plantações tem sido limitada pela disponibilidade de mudas, como a propagação convencional é através de sementes, que têm baixas taxas de germinação. Uma possível solução para produção em larga escala é por meio da embriogênese somática. O objetivo deste trabalho foi avaliar os efeitos das auxinas 2,4-D e picloram na indução de massas pró-embriogênicas em explantes foliares de Elaeis guineenesis híbrido Tenera e caracterizá-las, considerando as características embriogênicas, com analises citoquímicas e ultraestruturais. Para indução das massas pró- embriogênicas, fragmentos foliares de plântulas in vitro foram inoculados em meio de cultivo Y3 suplementado com 2,4-D ou picloram em diferentes concentrações $(0,0 ; 1,0 ; 3,0 ; 6,0$ e 9,0 mg.L-1 $)$. Após 90 dias foram avaliadas presença e ausência das massas celulares. Ambos reguladores de crescimento foram eficientes na indução destas massas, independentemente, das concentrações utilizadas. Como as massas celulares não eram homogêneas, estas foram classificadas quanto à cor e ao formato em quatro tipos: TIPO 1 - translúcido e alongado, TIPO 2 - translúcido e aquoso, TIPO 3 - bege e globular e TIPO 4 - branco e globular). De acordo com as características anatômicas e ultraestruturais os as massas celulares dos TIPOS 2, 3 e 4, foram consideradas com maior potencial embriogênico e portanto podem ser as mais promissoras para a propagação vegetativa em larga escala para o dendezeiro.

Palavras-chave: potencial embriogênico, reguladores de crescimento, cultura de tecidos, microscopia eletrônica de transmissão.

\section{REFERENCES}

AgROANALYsis. 2007. Biodiesel II. No Brasil, falta execução, n. 8, v. 27, ago. 2007.

Aslam J, Khan AS, Cheruth AJ, Mujib A, Sharma MP AND SRIVASTAVA PS. 2011. Somatic embryogenesis, scanning electron microscopy, histology and biochemical analysis at different developing stages of embryogenesis in six date palm (Phoenix dactylifera $\mathrm{L}$.) cultivars. J Biol Sci 18: 369-380.

Benjumea P, Agudelo J And Agudelo A. 2008. Basic properties of palm oil-diesel blends. Fuel 87: 2069-2075.

Bossola JJ AND RuSSELL LD. 1999. Electron Microscopy. $2^{\text {nd }}$ ed., Boston Jones and Bartlett Publishers, 670 p.

BRAVIN IC, VALENTIN YY AND YOKOYA NS. 2006. Formação de calos e regeneração de segmentos apicais de Hypnea musciformis (Wulfen) Lamouroux (Gigartinales, Rhodophyta): obtenção de culturas axênicas e efeitos da concentração do ágar. Rev Bras Bot 29: 175-182.

CANHoto JM, Mesquita JF AND CRUZ GS. 1996. Ultrastructural changes in cotyledons of Pineapple guava (Myrtaceae) during somatic embryogenesis. Ann Bot 78: 513-521.

Concenço G, Ferreira EA, Ferreira FA and Santos JB. 2007. Plasmodesmos: Transporte simplástico de herbicidas na planta. Planta Daninha 25: 423-432.

Duval Y, Gasselin TD, KonAN K AND PANNETIER C. 1988. In vitro vegetative production of oil palm (Elaeis guineensis JACQ) strategy and results. Oleagineux 43: 45-47. 
EEUWENS CJ. 1978. Mineral requirements for growth and callus initiation of tissue explants excised from mature coconut palms (Cocos nucifera) and cultured in vitro. Physiol Plant 36: 23-28.

FILliPI SB, APPEZZATO-DA-GLORIA B AND RODRIGUEZ APM. 2001. Variações morfológicas de embriões somáticos obtidos a partir de inflorescências de bananeira. Sci Agric 58: 711-716.

Filonova LH, BOZHKov PV, BRUKhIN VB, DANIEL G, ZHIVOTOVSKY B AND VON ARNOLD S. 2000. Two waves of programmed cell death occur during formation and development of somatic embryos in the gymnosperm Norway spruce. J Cell Sci 113: 4399-4411.

GHassan TQ, Mohamad I, AL-Widan B AND Ali O. 2003. Combustion performance and emissions of ethyl ester of a waste vegetable oil in a water-cooled fumace. Appl Therm Eng 23: 285-293.

GUERRA MP, TORRES AC AND TEIXEIRA JB. 1998. Embriogênese somática e sementes sintéticas. In: TORRES AC, CALDAS LS and BUSO JA (Eds), Cultura de tecidos e transformação genética de plantas. Brasília: Embrapa, $2^{\mathrm{a}}$ v., p. 534.

KANCHANAPOOM K AND DOMYOAS P. 1999. The origin and development of embryoids in oil palm (Elaeis guineensis Jacq.) embryo culture. ScienceAsia 25: 195-202.

Lam E, FuKuda H and GReEnBerg J. 2000. Programmed cell death of tracheary elements as a paradigm in plants. Plant Mol Biol 44: 245-253.

LAMB CRC, Milach SCK, PASQUALI G AND BARRo RS. 2002. Embriogênese somática e regeneração de plantas a partir de embrião maduro de aveia. Pesqui Agropecu Bras 37: 123-130.

LUIS ZG, BEZERRA KMG AND SCHERWINSKI-PEREIRA JE. 2010. Adaptability and leaf anatomical features in oil palm seedlings produced by embryo rescue and pre-germinated seeds. Braz J Plant Physiol 22: 209-215.

Martin AB, Cuadrado Y, Guerra H, Gallego P, Hita O, Martin L, Dorado A And Villalobos N. 2000. Differences in the contents of total sugars, starch and sucrose in embryogenic and non-embryogenic calli from Medicagoarborea L. Plant Science 154: 143-151.
Martine BM, Laurent KK, Pierre BJ, EugÉne KK HILAIRE KT AND JUSTIN KY. 2009. Effect of storage and heat treatments on the germination of oil palm (Elaeis guineensis Jacq.) seed. AJAR 4: 931-937.

Mikula A, TyKarsKa T, SKA, MZ, KuRAS M AND SKI JJR. 2004. Ultrastructural changes in zygotic embryos of Gentiana punctata L. during callus formation and somatic embryogenesis. Acta Biol Cracov Bot 46: 109-120.

Moura EF, Ventrella MC, Motoike SY, SÁ Júnior AQ, CARVALHO M AND MANFIO CE. 2008. Histological study of somatic embryogenesis induction on zygotic embryos of macaw palm (Acrocomia aculeate (Jacq.) Lodd. ex Martius). Plant Cell Tiss Org Cult 95: 175-184.

Stein VC, PAIVA R, VARGas DP, SOARES PS, AlVEs E AND NOGUEIRA GF. 2010. Ultrastructural calli analysis of Inga vera Willd. subsp. Affinis (DC.) T.D. Penn. Rev Árvore 34: 789-796.

Steiner N, Vieira FN, Maldonado S AND Guerra MP. 2005. Effect of carbon source on morphology and histodiffentiation of Araucaria angustifolia embryogenic cultures. Braz Arch Biol Technol 48: 895-903.

SteInMACHER DA, GUERRA MP, SAARE-SURMINSKI K AND LIEBEREI R. 2011. A temporary immersion system improves in vitro regeneration of peach palm through secondary somatic embryogenesis. Ann Bot 8: 1-13.

Steinmacher DA, Krohn NG, Dantas ACM, Stefenon VM, CLEMENT CR AND GUERRA MP. 2007. Somatic embryogenesis in peach palm using the thin cell layer technique: Induction, morpho-histological aspects and AFLP analysis of somaclonal variation. Ann Bot 100: 699-709.

THOMAS V AND RAO PS. 1985. In vitro propagation of palm oil (Elaeis guineensis Jacq var Tenera) through somatic embryogenesis in leaf-derived callus. Curr Sci 54: 184-185.

Verdeil JL, Hocher V, Huet C, Grosdemange F, Escoute J, FERRIEÁRE N AND NiCOLE M. 2001. Ultrastructural changes in coconut calli associated with the acquisition of embryogenic competence. Ann Bot 88: 9-18. 